\title{
Research on Innovation and Entrepreneurship of Minority's Education
}

\author{
Jialiang $\mathrm{He}^{1, \mathrm{a}}$, Wenxu Han ${ }^{1, \mathrm{~b}}$, Zhenghua $\mathrm{Li}^{* 2, \mathrm{c}}$ \\ 1 College of Information and Communication Engineering, Dalian Nationalities University, China \\ 2 College of Physics and Materials Engineering, Dalian Nationalities University, China

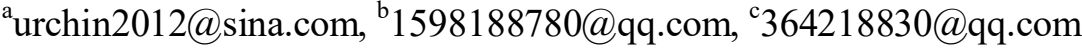

\begin{abstract}
Minority college students are the important part of the college students' group, also are the advanced elements in the minority areas of China. It is extremely urgent to strengthen the innovation and entrepreneurship education for minority college students and improve their innovative thinking and creativity. Minority college students have certain characteristics of ethnic diversity, regional differences, economic lag and historical and cultural complexity. However, they are also the crucial human resources for the economic and cultural development in the ethnic minority areas and the main force of rapid development. With the development of higher education popularization, like other students, they face the problem of employment difficulties. Through innovation and entrepreneurship education, colleges can promote the innovative spirit and entrepreneurial awareness, strengthen the comprehensive quality education and ensure the quality of minority college students. This will not only alleviate the current employment pressure of them, but also promote the prosperity and development of politics, economy and culture in ethnic minority areas.
\end{abstract}

Keywords-Innovation Education; Entrepreneurship Education; Teaching Quality; Minority College Students

\section{INTRODUCTION}

Deepening the reform of innovation and entrepreneurship education in colleges and universities is an urgent need for the country to implement an innovation-driven development strategy, promote economic upgrading and efficiency upgrading, and is an important measure to promote comprehensive reform of higher education and promote higher quality entrepreneurship for college graduates. Recently, the Ministry of Education requires: All local colleges and universities should take the improvement of education quality as the starting point and the foothold of innovation and entrepreneurship education reform, and promote the organic integration of professional education and innovation and entrepreneurship education according to the requirements of talent training and innovation and entrepreneurship education. Out, college students' innovation and entrepreneurship are an important part of China's higher education and a clear requirement for high-quality education.

At the same time, with the continuous development of China's economy, the acceleration of the construction of socialist undertakings, and the steady advancement of minority higher education, the number of minority college students has been increasing the core strength of minority college students as the future economic development of the ethnic regions. A resource pool for social and economic development in ethnic minority areas. However, due to the particularity of ethnic minorities, minority college students face more employment difficulties than non-minority college students. Therefore, strengthening the innovation and entrepreneurship education of minority college students is of great significance to the development of students themselves and ethnic areas.

\section{THE SIGNIFICANCE OF STRENGTHENING THE EDUCATION OF ETHNIC MINORITY COLLEGE STUDENTS}

Conducive to improving the comprehensive quality of minority college students and promoting all-round development. Minority college students mainly come from economically backward ethnic areas [1]. They are affected by the natural environment, customs and education level. So that to a certain extent, their psychological endurance is not strong, their ability to communicate with the outside world, their innovative spirit and entrepreneurial awareness are relatively weak. And their comprehensive quality is low. Innovative and entrepreneurial education in colleges and universities can enable minority college students to master professional knowledge and skills, enrich and improve knowledge structures, make cognitive, communication and leadership skills better, stimulate the creative way of thinking, promote their knowledge and skills transformation, and improve their comprehensive quality. Then realize their all-round development.

Conducive to helping minority college students to promote employment through entrepreneurship and achieve self-worth. Youth is the hope of the country and the nation. Innovation is the soul of social progress. Entrepreneurship is a vital way to promote economic and social development and improve people's livelihood. Young students who are the lively force of innovation and entrepreneurship are imaginative and creative. With the popularization of higher education, the employment situation of college graduates is becoming more and more serious. Therefore, the precise push of innovation and entrepreneurship education for minority college students is conducive to stimulating the entrepreneurial interest, fostering entrepreneurial awareness, promoting employment through entrepreneurship and increasing the employment of minority college students. It can also help them solve employment problems, moderate China's increasingly severe employment situation and increase employment rate and achieve self-worth [2]. 
Conducive to promoting the harmonious development of ethnic areas. With the continuous development of the social economy, the level of economic and social development in ethnic areas has been greatly improved, and also for people's lives. However, to cultivate a team of minority college students with innovative spirit, entrepreneurial awareness and entrepreneurial potential means that it will establish an adequate store of human and intellectual resources for the economic and social development of ethnic minority areas, who can combine their knowledge of innovation and entrepreneurship together and become the pioneers of regional nation industrial innovation, also promote local economic and social development in a related manner. Social stability and economic development are inseparable. Hence it's of great significance to alleviate social conflicts and promoting social unity and stability to make economic and social progresses in ethnic minority areas.

\section{THE STATUS OF INNOVATION AND ENTREPRENEURSHIP EDUCATION FOR MINORITY COLLEGE STUDENTS}

Minority college students lack comprehensive quality. Most minority college students have 'congenital deficiency' in their comprehensive quality. Most of them come from remote economic backward areas. First of all, due to the lack of necessary innovative enlightenment education and the influence of traditional culture, they generally lack exploration spirit and are weak in the sense of innovation, also have the lack of divergence and flexibility in thinking mode [3]. After coming to the prosperous cities in the mainland, changes in living environment, differences in culture and education and barriers to language communication have appeared. They often have a strong sense of inferiority and self-esteem, lack initiative to communicate with others and the awareness of innovation and entrepreneurship. And they don't have firm will and confidence in this area, also lack decisiveness and selfcontrol. All of these factors affect the innovation and entrepreneurship education of minority college students.

The pattern of innovation and entrepreneurship education in colleges and universities falls behind. China's colleges and universities' innovation and entrepreneurship education started late, still in the exploratory period, and has not formed a sound scientific innovation and entrepreneurship teaching system. The curriculum is not reasonable enough, the professional education is not scientifically combined with innovation and entrepreneurship education, the teaching method is not effective, especially its insufficiency in the guidance of entrepreneurial practice teaching [4]. Colleges and universities have not fully recognized the characteristics of minority college students and have not established targeted innovation and entrepreneurship education courses, especially lacking the spirit of innovation and entrepreneurship and the education of improving their confidence and courage. Thus the results are not significant enough.

Innovation entrepreneurship education teachers can not meet the actual needs. First of all, many teachers have problems in the unclear positioning and cognitive bias of innovation and entrepreneurship education. They do not understand that this is the inherent requirement of the reform and development of higher education. And they do not take it as a way to improve the students seriously. Secondly, innovation and entrepreneurship education is the sublimation of quality education, which pays attention to the cultivation of students' comprehensive ability, but the professional teachers in colleges and universities in China generally go from one 'school gate' to another 'school gate'. They have not experienced the actual work, basically staying in the theoretical knowledge, and lacked the experience and skills of innovation and entrepreneurship. Then, it is not enough to study the characteristics of minority college students and link innovation and entrepreneurship with them effectively, which makes it difficult to stimulate the enthusiasm of minority college students to participate in innovation and entrepreneurship activities.

\section{STRENGTHEN THE PATH OF INNOVATION AND ENTREPRENEURSHIP EDUCATION FOR MINORITY COLLEGE STUDENTS}

Create a good innovation and entrepreneurship education campus environment. Minority students are different from Han nationality students in that they have strong national feelings and different lifestyles [5]. The idea of campus innovation and entrepreneurship education should reflect individuality and humanistic care. It should be noted that we should respect the culture, religious beliefs, living habits and individual characteristics of minority college students, and make minority college students improve the psychological identity innovation and entrepreneurship education through our caring education. We also should guide minority college students to establish a positive and healthy entrepreneurial concept, pay more attention to the promotion of campus activities and cultivate the teamwork spirit of minority college students through colorful campus activities, such as ethnic customs festivals and ethnic carnival activities.

Strengthen the establishment and promotion of the model of innovation and entrepreneurship in minority college students In view of the problem of weak enthusiasm of minority universities in innovation and entrepreneurship, we should do a good job in guiding public opinion and play a leading role in minority college students by establishing innovative entrepreneurship models and demonstrating successful entrepreneurial cases. First of all, the school can hold innovative and entrepreneurial lectures, invite some students who participate in the innovation activities to show their ideas, and root the concept of innovation and entrepreneurship in the hearts of minority college students. Secondly, invite some successful ethnic minorities who are the resources outside the school. We can organize entrepreneurship forums for students to answer questions of minority college students' concerns. At the same time, enterprises can also provide practical positions for students to experience the journey of a company from creation to development and to success. It can light up the enthusiasm of innovation and entrepreneurship for minority college students.

Improve the curriculum system of minority college students' psychological quality in innovation and entrepreneurship. Combining the current experience of innovation and entrepreneurship education at home and abroad, according to the characteristics of multiculturalism of minority 
students, the psychological quality education curriculum is incorporated into the existing innovation and entrepreneurship education system of colleges and universities in order to cultivate the quality of innovation and entrepreneurship of minority college students. It roots in and respects the differences and characteristics of national culture, strengthens the education of minority college students' psychological quality in innovation and entrepreneurship through classroom teaching, humanistic care, psychological guidance, psychological counseling, etc. It can cultivate innovative spirit, entrepreneurial concept, entrepreneurial awareness and entrepreneurial psychology ability [6] and establish a personalized innovation and entrepreneurship education concept based on minority students, motivate them to be determined to become talents and work hard to revitalize the country and nation.

Pay attention to multi-ethnic integration in the innovation and entrepreneurship education system. Minority college students are the main force in the social and economic development of ethnic areas, and the cultivation of innovative and entrepreneurial abilities will help minority college students to better build their hometowns. For colleges and universities, especially ethnic colleges and universities, first of all, it is necessary to ensure that minority college students will participate in the "Da Chuang Project". The proportion of teachers and research projects is not lower than the proportion of minority students in the school. To ensure the accuracy of this measure, specific information such as gender and ethnic minority should be added in various types of declarations. In addition, in the school for various types of innovation and entrepreneurship practice activities, such as academic competitions, we should encourage the formation of multiethnic embedded teams, which can strengthen the unity and cooperation of all ethnic groups and learn from each other.

Build a team of qualified teachers for minority students' innovation and entrepreneurship education. Cultivating and building a high-level team of innovative and entrepreneurial education teachers is the key to ensuring the smooth implementation of innovation and entrepreneurship education in colleges and universities. In colleges and universities, especially in ethnic ones, teachers need to have a theoretical and capacity reserve of multicultural education, including the sense of responsibility for the education of ethnic minority college students, the mastery of ethnic cultural diversity and the ability to interact with students of different cultural backgrounds etc. According to the characteristics of ethnic minority students, hobbies, future employment areas, we should make targeted and personalized instructional teaching [7]. College teachers generally lack the background of multicultural education before entering the job, so this requires universities to strengthen the content of multicultural education in the new teacher training. In addition, the teacher's own innovative practice ability plays a vital role in the cultivation of minority college students' practical innovation ability. In the evaluation system of teachers' work, there will be indicators that reflect the training work of minority students. We also should encourage teachers to actively organize and guide minority students to participate in the practice of innovation and entrepreneurship. Then it will be better to have a certain inclination in the evaluation of job titles and promotion of positions to the teachers who have made outstanding contributions, which can stimulate the enthusiasm of teachers and ensure the sustainable development of the faculty.

Strengthen the practice of minority college students' innovation and entrepreneurship activities. Innovative entrepreneurship education is a very practically educational activity. Colleges and universities should actively build a platform for entrepreneurial practice for minority college students and comprehensively expand the training path for minority college students' entrepreneurship education from both the school and the outside. The school can establish innovation and entrepreneurship practice platforms such as innovation studios, innovation centers and school entrepreneurship incubators, supplemented by various innovation and entrepreneurship competitions. Through collaboration with research institutes and enterprises and the use of off-campus resources, we can provide consultation and guidance for minority college students' innovation and entrepreneurship outside school, and also provide relevant internship positions as much as possible so that minority college students can feel the entrepreneurial atmosphere and specific business practices to improve their comprehensively entrepreneurial quality under the real entrepreneurial environment. Besides, colleges and universities should take the initiative to strengthen contact with ethnic minority students, establish a returning service mechanism, arrange minority college students to return to their hometowns to carry out innovation and entrepreneurship practice, realize the close integration of minority college students' innovation and entrepreneurship education and regional environment, and give a full play to the combination of production, learning and research, which provide a platform and guarantee for minority college students to carry out innovative and entrepreneurial practice activities.

\section{CONCLUSION/SUMMARY}

Innovation and entrepreneurship education has become an important part of China's education. Colleges and universities should continuously strengthen the practice of innovation and entrepreneurship, enhance the teaching ability of young teachers' innovation and entrepreneurship education, and build a campus innovation and entrepreneurship culture. This requires us to be good at summarizing and discovering the problems existing in entrepreneurial innovation in the future teaching, and seeking ways to improve in time so that we can continue to improve and carry out well. Innovative entrepreneurship education work.

\section{REFERENCES}

[1] Y.F.Hu, A Probe into the Realization Path of Innovation and Entrepreneurship Education [J], Journal of Pingxiang College in Chinese, Vol. 32 (2015), p. 86-88

[2] T.Dong. Research on Problems and Countermeasures of Precision Education for Innovation and Entrepreneurship of Minority College Students [J], China Higher Education in Chinese, Vol.7 (2016), p. 179181.

[3] X.J.Liao, Y.Li, L.Qian, Z.Z.Li and Z.L.Huang, Experiences of Young Teachers in Ethnic Areas in Carrying out Innovation and 
Entrepreneurship Education [J], The Guide of Science \& Education in Chinese, Vol. 13 (2017), p. 73-74.

[4] Z.K.Sun, Analysis of the Current Situation of Innovation and Entrepreneurship Education for Minority College Students [J],Modern Society in Chinese, Vol. 13 (2017), p. 73-74.

[5] C.L.Li, Research on Countermeasures of Innovation and Entrepreneurship Education for Minority Students [J],China Higher Education in Chinese, Vol. 11 (2017), p. 177-177.
[6] R.Shen, Problems and Countermeasures of Entrepreneurship Education for Minority College Students [J], The Party Building and Ideological Education in Schools in Chinese, Vol. 4 (2015), p. 71-72.

[7] P.Hu, Problems and Countermeasures of Training Innovative Talents for Minority Nationalities in Colleges and Universities [J], Tibet Education in Chinese, Vol. 6 (2017), p. 33-38. 